\title{
The Principal's Leadership in Improving the Teachers Professional Competence at SMP Islam Singkil at Aceh Singkil Regency.
}

\author{
Abdil $^{1 *}$, Murniati $^{2}$, Niswanto $^{3}$ \\ ${ }^{1}$ Master of Education Adminitration, Syiah Kuala University, Indonesia \\ ${ }^{2}$ Syiah Kuala University, Indonesia \\ *Corresponding email: abdil_spd@yahoo.com
}

Received: 12 March 2021

Accepted: 15 April 2021

Published: 30 August 2021

Abstract: The purpose of this study is to find out: the principal's program, strategies program and obstacles faced by the principal in increasing teacher professional competence. This study uses descriptive method with qualitative approach. The subjects were principal, teachers and supervisor. The results showed that: 1) the principal's program in enhancing the teachers professional competence by implementing discusion forum in the early school year together with vice principal curriculum section, the student affairs, facilities, teachers, committee, inspectors, and the discussion results are described in the school program. 2) The principal's strategy in improving teacher professional competence creates a good climate, providing opportunities to every teacher to continue their education, rewarding outstanding teachers. 3) Supporting factors in solving obstacles such as: location of madrasas, giving fair assignments based on background of education, trust and support community, providing good opportunities in improving teacher professionalism, including teachers training, workshops, training, supporting teaching facilities and learning processes and transparent financial management as well.

Keywords: leadership, principals, professional competence.

Abstrak: Tujuan penelitian ini adalah untuk mengetahui: program kepala sekolah, program strategi dan kendala yang dihadapi kepala sekolah dalam meningkatkan kompetensi profesional guru. Penelitian ini menggunakan metode deskriptif dengan pendekatan kualitatif. Subyeknya adalah kepala sekolah, guru dan supervisor. Hasil penelitian menunjukkan bahwa: 1) program kepala sekolah dalam meningkatkan kompetensi profesional guru dengan melaksanakan forum diskusi di awal tahun ajaran bersama-sama dengan wakil kepala sekolah bagian kurikulum, kesiswaan, fasilitas, guru, komite, pengawas, dan hasil diskusi dijelaskan dalam program sekolah. 2) Strategi kepala sekolah dalam meningkatkan kompetensi profesional guru menciptakan iklim yang baik, memberikan kesempatan kepada setiap guru untuk melanjutkan pendidikannya, memberikan penghargaan kepada guru yang berprestasi. 3) Faktor pendukung dalam mengatasi kendala seperti: lokasi madrasah, pemberian tugas yang adil berdasarkan latar belakang pendidikan, kepercayaan dan dukungan masyarakat, memberikan peluang yang baik dalam meningkatkan profesionalisme guru, termasuk pelatihan guru, lokakarya, pelatihan, fasilitas pengajaran yang mendukung dan proses pembelajaran dan juga pengelolaan keuangan yang transparan

Kata kunci: kepemimpinan, kepala sekolah, kompetensi profesional.

\section{To cite this article:}

Abdil, Murniati \& Niswanto. (2021). The Principal's Leadership in Improving the Teachers Professional Competence at SMP Islam Singkil at Aceh Singkil Regency. Jurnal Pendidikan Progresif, 11(2), 392399. doi: 10.23960/jpp.v11.i2.202119. 


\section{INTRODUCTION}

Education is a process to improve, revise, change the knowledge, skills and attitudes and behavior of a person or group of people to educate human life through certain role, teaching and research activities (Dzhandzhugazova, 2018; Dee \& Leisyte, 2017; Schwendimann \& Linn, 2016). The education process shows that there is activity through a dynamic interaction and consciously carried out an effort to achieve the desired goal. Therefore, the implementation of education is always active and planned (Halverson \& Rosenfeld, 2019; Montaperto \& Henderson, 2017).

The goverment role nomber: 19 Year: 2005 about Education Standards (PP Number: 19 year 2005), stated that, there are eight standards that must be met in implementing education. The eight education standards are: Content Standards, process standards, graduate competency standards, standards of educators and education personnel, standards of facilities and infrastructure, management standards, funding standards and educational assessment standards. One of standard which is considered directly related to the quality of graduates indicated by the competence of graduates is the standard of education and education personnel. It means that in order to achieve the desired quality of graduates, the quality of teaching staff(teachers), and education staff (principals, supervisors, librarians, administrative staff, messengers) must be improved.

Dynamic and effective leadership is the most basic potential and hard to find, but it does not mean that a leader cannot be a dynamic and effective leadership (Luria et.al., 2019; Gage \& Smith, 2016). Understanding leadership theory will be able to increase his understanding of himself, knowing the weaknesses and strengths of the potential on him, and will be able to increase his understanding on how he should lead his subordinates (Winton, Palmer, \& Hughes, 2018; Magsaysay \& Hechanova, 2017). An effective leader has advantages in terms of: (1) Intelligence Level, (2) Situation sensivity, (3) Effective Work , (4) Initiative, and (5) Individuality (Miao et.al., 2018). The activities of the principal as a manager include the management of $3 \mathrm{M}$, first, human beings as the main driving factor in school activities, second, money as capital activity, third, method as a tool to direct humans and money to be effective in achieving goals (Harrison \& Lock, 2017). But the role of the principal as a manager is not enough. Successful leader and failure leader is determined by the nature and style of leadership in directing dynamics group. Leadership of a leader will be able to distinguish characteristics of an organization from other organizations (Van Quaquebeke \& Felps, 2018).

The principal of a madrasah (school) is a leader who has an important role in developing the quality of education (Shulhan, 2018; Suhan, Thahir, \& Mohammad, 2017). The principal of a madrasah (school) as administrastor must be able to maximaze the resources. As a manager, principal should be able to cooperate with others to lead people in a organization. As an educational leader, principal should be able to shake and coordinate potential of the human being to achieve education goals. As a supervisor, principal should be able to help teachers improve students' capacity to maximaze teaching learning activity. Principal of a madrasah is a functional staff teacher who is given an additional task to lead a madrasah and teacher who gives lessons to the students.

If so, principal expected to manage educational institutions to develop a better quality that can be promised in the future. Every principal tsanawiyah as organizational leaders need to master and has the ability to motivate the subordinates, in order to influence his/ her subordinates to understand the subordinates needs. According to the Regulation of the Minister 
of Education and Culture No. 13 Year 2007 on standard principals / madrasah: "there are five (5) dimensions of competence, principals should have the competence or capability that includes the dimensions of personal competency, managerial, entrepreneurial, supervision and social". Managers have an efficiency way to do, daily business, a short way to do things correctly. Further explained that managers tend to think of his people as a resource, and wonder to know what their income and how he could change them become heroes.

Profesionals are those who carry out the duties professionally, carry out his duties in a professional manner based on the the role which should have professional expertise, professional responsibility, and loyalty and the profession gained through education and professional training organized by the government. In Law Number 20 of 2003 concerning the national education stem 39 paragraph 2, Education is the professional staff tasked with planning and implementing the learning process, assessing the learning outcomes of conducting guidance and training, as well as evaluating and serving the community. When someone is considered as a professional, if he does his work, he always holds and aware of: (1) Work Ethics, (2) independent (free from outside pressure), (3) Fast (productive), (4) Right (effective), (5) Efficient and (6) Innovative and (7) based on the principles of excellent service.

The teacher is a element resource that determines the success of education in madrasah, because the teacher is the human that is closely related to student and daily education activity in Madrasah (Asadollahi \& Mirzaei, 2019). The teacher's professional duties include a chain activity starting from planning learning, implementing, evaluating to follow-up evaluations (Lee \& Ritchotte, 2019; Juhler, 2018; Raymond, J. K. (2017). In addition, teachers are also required to have an understanding of insight education, understanding of the learners and should be able to develop the potential of learners with skills (Loii et.al., 2018). Teachers must have the competence, skills and behaviors that should be had and mastered and lived out in implementing his duty. Professional teachers carry out tasks toward the demands of the profession or in other words have the ability and attitude toward the demands of the profession. A professional runs his activities based on professionalism, and it is not an amateur. A professional will continuously improve quality consciously, through education and training. Professional teachers must have competencies that must be mastered including: (1) Mastering teaching materials or subject matter, (2) managing teaching and learning activity (3) managing classes (4) using media to know learning resources, (5) mastering educational foundations, (6) managing teaching and learning activities, (7) assess student learning achievement, (8) recognize the functions and services of guidance and counseling, (9) recognize and organize school administration, and (10) understand and interpret the results of research for the benefit of learning. All of these are very appropriate with the Declaration of the Minister for the Utilization of State, regarding the instructions for implementing teacher functional positions and the credit numbers as follows: (1) Arranging the teaching program, (2) preparing the teaching syllabus (3) compiling a plan for implementing learning, (4) carrying out learning activities, (5) compiling a measuring instrument / question according to subjects (6) evaluating and evaluating learning processes and outcomes (7) analyzing the results of the assessment, (8) carrying out improvement and enrichment learning by utilizing assessment and learning outcomes, (9) becoming supervisors in evaluating and evaluating school and national learning processes and outcomes, (11) guiding teachers beginners with induction programs, (12) 
guide students in the learning process extracurricular activities, (13) carry out selfdevelopment, (14) carry out scientific publications.

\section{METHODS}

Based on a research problem entitled "Principal Leadership in Improving Teacher Professional Competence at MtsN Singkil Aceh" will use qualitative descriptive. The location of the study was conducted at Singkil State MTs located in Aceh City, Singkil Regency. Data collection techniques, researchers use three types of data collection techniques, namely: collection techniques, interview techniques, and documentation techniques, and in data collection as well. Data analysis was carried out in three steps, namely (1) data reduction; (2) displays, and (3) draws conclusions and verification. Subjects in this study were principals, supervisors, and teachers in Singkil Regency. Research collecting data in field reports and compiling systematicallywill get conclusions. The credibility test of this research uses tranggulation so that the data obtained can be verified.

\section{RESULTS AND DISCUSSION}

Principal's Leadership in increasing Teacher Professional Competence

Principal Program in Improving teacher Professional Competence

The results of the study identified that the madrasah program, which was conducted by the principal have been running at the right track. This is proved by the activities of fostering and developing the improvement of professional teacher competence carried out by the principal of the madrasah. Therefore, the professional level of teachers at MTsN Aceh Singkil Regency has undergone a change in a positive direction, even though there are a lot of things that need to be improved overall. Designing program to improve the professional competence of teachers and collaboration between the program and others is based on a professional attitude and a good collaboration and comitment in carrying out any program that has been planned in the meeting forum.

The fact that is proven through field findings cannot be left alone, either by the principal of the madrasa itself or by several parties, because what happens in the field is proven by the real situations and conditions. There are many good programs designed by the principal of madrasah as an effort to improve the professional competence of the teacher. In an effort to improve teacher performance in teaching and learning activity in the classroom. Ideally, the principal of the madrasah has initiatives and seminars on the main tasks and responsibilities as a madrasah leader. If the principal of the madrasah has good performance, it will dominate many activities in the madrasah and the principal of the madrasah has the authority to make decisions and policies to be implemented in the madrasah. Sucessful principal are those who has program to increase teacher professional, because it affects to the quality of learning. There are two things that must be considered, the principal role as a central force which is the driving force of school life. The principal understands their duties and functions for the success of the school, and has concern for teachers, staff and students.

The ability of the principal to make movement of subordinates is a very important factor to carry out the function as a leader in the madrasah. With the leadership of a madrasah leader towards efforts to improve the quality of teachers can be more motivated to develop their knowledge so that new innovations arise in learning.

To improve the professionalism of the teacher, the principal of the madrasah as a leader should provides opportunity to motivate the teacher to carry out activities that lead to improve the quality of teachers in all activities related to 
teacher competencies (Liu, \& Hallinger, 2018). Such as participating in MGMP, training, teacher training courses, training in scientific writing and providing motivation to teachers to always develop their insights through various available media such as libraries, IT labs, etc., and providing opportunities for teachers who wish to pursue higher education.

The principal of educational institutions welcomes to the problems that arise in the implementation of learning activities faced by teachers, so that they make new things for a good learning activities according to their abilities and support. Teacher creativity can be developed throght the of learning tools, lesson plans , Syllabus, Prota, Prosem, Evaluation, then the learning activities will be maximal. Principals Indicators can effectively be observed on the three main topics as follows: (1) cominment to the vision of the school in carrying out its duties and functions, (2) make the vision of the school as a guide to manage and lead school, (3) always focuses its activities on learning and teacher performance in the classroom.

The role of principal of the madrasah has a huge influence on the continuity of the dynamics education in the madrasah. The importance of the creativity of madrasah leader in managing the madrasah program is needed till the followi-up aspects of the implementation of the madrasah program as well. If the mindset of the madrasah focuses on the education development, then it can be ascertained that education in madrasah will be better.

\section{Principal Strategies to Improve Teacher Professional Competence}

Based on the results of the study, the main way to improve the teacher professional competence at MTsN Singkil is to analyze the programs that have been made by the madrasah based on understanding vision and mission, while the task of the head of the madrasah is exercising authority on the implementation of education in madrasah according to their duties and functions. To carry out the principal tasks of the madrasah as administrative tasks, it should be preceded by looking at planning program that will be carried out in order to improve the quality of education staff. The strategy of the principal is divided into two parts of activities, namely formal and informal, a strategy carried out by the headmaster, namely:

\section{Formal Strategy}

Professional teacher training, teacher seminars related to achievement with educational quality, and character attainment are conducted. The principal of the madrasah often includes the teachers in training, outreach, seminars, training and so on, in order to improve achievements and insights about teacher education. The education and training provided a form of the madrasah's principal as an active role in increasing the teacher's professionalism and to improve the quality of the teaching staff.

\section{Supervision}

Implementation of supervision is carried out with the aim of developing abilities in the teaching and learning process. According Suetjipto and Kosasi (2013) that: "The supervision activities carried out through a variety of teaching problemsolving process. The goal is to improve the effectiveness and efficiency of the teaching and learning process. "The supervision of MTs Negeri Singkil in Aceh Singkil Regency was carried out directly by the principal of madrasa and supervises every semester.

\section{Non Formal Strategy}

a. Discipline

The principal of the madrasah applies discipline both for the students and teachers to improve discipline because the teachers are as role models for students at school. 


\section{b. Motivasi Guru}

The principal needs to encourage or motivate teachers to be more creative and minovatif in the learning process in the classroom as an effort to improve the professional competence of teachers.

This activity is carried out by the principal of madrasah to provide the widest opportunity to the teachers in actualizing themselves in accordance with developments and information and technology that is rapidly change.

Obstacles of the pricipal of the madrasa in Increasing Teacher Professional Competence

Obstacles of the pricipal of the madrasa in Increasing Teacher Professional Competence

The obstacle faced by the madrasah's principal in implementing the program to improve teacher professional competency in singkil public MTs is realated to financial so far, in improving teacher competency does have enogh money. There are some teachers who are not able to develop learning tools properly, there are teachers who have have low motivation to improve their competence, the limited time and facilities and infrastructure are the proble and the limitation of the time of the teachers when attending the training as well. Because of this issus, the principal of the the madrasah must think of the right and effective stategy to overcome the existing problems, so that the principal of the madrasa is expected to be able to control low competence of teachers in managing teaching activity.

There are other several supporting factors in making better madrasah/ school such as strategic geographical outputs of madrasas as well as community trust and support for madrasas in carrying out policies. In increasing the professionalism of teachers at MTsN Singkil supported by the availability of supporting facilities for the implementation of the learning process, the occurrence of good relations among fellow madrassah, a conducive environment, and transparant and accountable management of madrash administration and finance.

\section{- CONCLUSIONS}

Headmaster Program in improving the professional competence of teachers are prepared to carry out the consultative meeting with the teachers / subordinate at beginning of school year together with the vice principal, teachers, school committee, superintendent. Program conducted by the principal in improving the professional competence of teachers is a must for teacher to create lesson plans, prota, prosem, syllabi, etc., and the teachers have to prepare teaching materials before peroses learning and teaching implemented.

The principal's strategy in enhancing teacher professional competencies includes following teachers in activities: training in fields of study, workshops, and seminars, writing scientific work and conducting periodic supervision in each semester. Creating conducive climate provides a ballance opprtunity in professional development of teachers, refreshment, and a fair division of tasks and engage with teachers.

The obstacles faced by the principal of madrasah in improving teacher professional competence are the low competency of the principal in planning the program, there are teachers who have not mastered Computer Science Technology, such as low income so can not join training, low motivation of teachers to improve competence, limited time in participating in education and training, and the weakness of teacher teaching staff. So that it becomes a teacher's obstacle in improving creating planning and implementation in madrasas.

Other supported factore to make better madrasah/ school are strategic location of the madrassa, trust and community support to madrasas, pursuing policies that have been 
agreed, the availability of facilities to support the implementation of the learning process, good working between madrasah citizens, good madrasah environment, transparent and accountable administrative and financial management as well.

\section{REFERENCES}

Asadollahi Kheirabadi, M., \& Mirzaei, Z. (2019). Descriptive valuation pattern in education and training system: a mixed study. Journal of Humanities Insights, 3(01), 7-12.

Dee, J., \& Leisyte, L. (2017). Knowledge sharing and organizational change in higher education. The Learning Organization .

Dzhandzhugazova, E. A., Blinova, E.A., Orlova, L. N., Romanova, M. M., \& Davydovich, A. R. (2018). Innovations in science and industry-specific education. Modern Journal of Language Teaching Methods, 8(3), 10-21.

Gage, T., \& Smith, C. (2016). Leadership intelligence: Unlocking the potential for school leadership effectiveness. South African Journal of Education, 36(4), 19.

Halverson, R., \& Rosenfeld Halverson, E. (2019). Education as design for learning: A model for integrating education inquiry across research traditions.

Harrison, F., \& Lock, D. (2017). Advanced project management: a structured approach. Routledge.

Juhler, M. V. (2018). Assessment of Understanding: Student Teachers' Preparation, Implementation and Reflection of a Lesson Plan for Science. Research in Science Education, 48(3), 515-532.

Lee, C. W., \& Ritchotte, J. A. (2019). A Case Study Evaluation of the Implementation of Twice-Exceptional Professional
Development in Colorado. Journal for the Education of the Gifted, 42(4), 336361.

Liu, S., \& Hallinger, P. (2018). Principal instructional leadership, teacher selfefficacy, and teacher professional learning in China: testing a mediated-effects model. Educational Administration Quarterly, 54(4), 501-528.

Looi, C. K., Sun, D., Kim, M. S., \& Wen, Y. (2018). The impact of a professional development model for a mobilized science curriculum: a case study of teacher changes. Research in Science \& Technological Education, 36(1), 86-110.

Luria, G., Kahana, A., Goldenberg, J., \& Noam, Y. (2019). Leadership Development: Leadership Emergence to Leadership Effectiveness. Small Group Research, 50(5), 571-592.

Magsaysay, J. F., \& Hechanova, M. R. M. (2017). Building an implicit change leadership theory. Leadership \& Organization Development Journal.

Miao, C., Humphrey, R. H., Qian, S., \& Pollack, J. M. (2018). Emotional intelligence and entrepreneurial intentions: an exploratory meta-analysis. Career Development International.

Montaperto, R. N., \& Henderson, J. (2017). China's Schools in Flux: Report by the State Education Leaders Delegation, National Committee on United StatesChina Relations. Routledge.

Raymond, J. K. (2017). Evaluating One Public School District's Teacher Evaluation Program and its Implementation: A Qualitative Case Study. Saint Mary's University of Minnesota.

Schwendimann, B. A., \& Linn, M. C. (2016). Comparing two forms of concept map critique activities to facilitate knowledge 
integration processes in evolution education. Journal of Research in Science Teaching, 53(1), 70-94.

Shulhan, M. (2018). Leadership style in the madrasah in Tulungagung: how principals enhance teacher's performance. International Journal of Educational Management.

Suhan, S. Z. D., Thahir, L. B. M., \& Mohammad, A. M. B. (2017). The Practice of Spiritual Leadership of Islam Principal Madrassas Aliyah Country and the Relationship with Culture Madrassas. Advanced Science Letters, 23(9), 8966-8970.

Van Quaquebeke, N., \& Felps, W. (2018). Respectful inquiry: Amotivational account of leading through asking questions and listening. Academy of Management Review, 43(1), 5-27.

Winton, S. L., Palmer, S., \& Hughes, P. J. (2018). Developing Leadership for Increasing Complexity: AReview of Online Graduate Leadership Programs. Journal of Leadership Education, 17(1). 